\title{
Sustainable transport solutions at a crossroads in developing countries: insights and perspectives
}

\author{
J. Chakwizira ${ }^{1}$, P. Bikam ${ }^{1}$ \& T. A. Adeboyejo ${ }^{2}$ \\ ${ }^{1}$ University of Venda, School of Environmental Sciences, South Africa \\ ${ }^{2}$ Ladoke Akintola University of Technology, Nigeria
}

\begin{abstract}
This paper reviews the solutions to the matters of sustainable transport at a crossroads in developing countries. In the process, the paper recommends re-thinking sustainable transport solutions in developing countries, given that current and previous efforts have failed to permanently reverse problems of automobile dependency, an inefficient public transport system and network traffic congestion for example. In addition, land use and transport planning actions and interventions have been found to promote fragmentation and gentrification of spaces, places and people. This paper analytically reviews desktop studies covering the sustainable transport from developing countries to establish the existing situation as well as crafting a policy and intervention lever departure points. Making use of over 20 years of research, consultancy and practical experience, we aim to define possible future sustainable transport intervention levers and focus on areas within developing countries.
\end{abstract}

Keywords: transport, sustainable, fragmentation, integration, developing countries.

\section{Introduction}

Sustainable growth needs sustainable transport, and sustainable transport generates sustainable growth (Kumar and Barrett [1] and World Bank [2]). This dual role of the transport sector underlies its importance for economic development. Countries which do not have a functioning and sustainable 
transport infrastructure in place cannot guarantee their long-term development. In the new millennium, one can argue that the deployment of sustainable transport systems and their maintenance is at the core of the new development agenda in developing countries (Kumar and Barrett [1] and Federal Ministry for Economic Cooperation and Development [4]). Sustainable mobility can be defined as the initiatives and interventions aimed at establishing transport structures that cater for the present and projected demand for mobility, accessibility and that enable the development of a dynamic economy (Chakwizira [5], Chakwizira et al. [7] and World Bank [2]). In addition, sustainable transport systems, measures and actions must be seen to explicitly assist in poverty reduction, in the widening of socio-economic access to opportunities and to be in sync with the overall goals of sustainable development.

In many developing countries mega cities and large conurbations, such as Mumbai, Sao Paulo, Lagos, Nairobi and Johannesburg, urban traffic is in distress (Kumar and Barrett [1], Federal Ministry for Economic Cooperation and Development [4], Chakwizira [5] and Chakwizira et al. [6]). Traffic jams, ear-deafening noise and smog - caused by the vast numbers of trucks, buses, minibuses and mopeds that obstruct roads and junctions - are a direct result of increasing urbanisation and motorisation. Many of the urban residents (motorists and pedestrians) spend hours commuting to work, school or seeking to access various facilities. Even more alarming is the situation in rural areas, where roads and means of transport are lacking and access to employment opportunities, to health care facilities, to schools or even to the nearest urban market is limited (Federal Ministry for Economic Cooperation and Development [4], Chakwizira [5], Kumar and Barrett [1], Haq and Schwela [8] and Chakwizira et al. [6]). Without adequate mobility, there is little possibility of overcoming poverty. Consequently efforts aimed at improving individual mobility can be viewed as a prerequisite for overcoming poverty. Without access to affordable transport, it is almost impossible to reach health care facilities, travel to and from schools and institutions of further education, find better-paid jobs and carry out trade activities, cultivate social contacts and/or escape isolation (Chakwizira et al. [7], Haq and Schwela [8] and World Bank and ADB [9]). This is especially valid for women, since they are often heavily dependent on non-motorised means of transport and public transport.

At the beginning of the new millennium, approximately 50 per cent of the world's population lived in cities (World Bank [2] and UNEP [10]). Projections up to 2025 indicate that the proportion of people, especially in developing countries, that will be living in urban areas will increase dramatically (World Bank and ADB [9]). In a growing number of mega cities with more than ten million inhabitants, the quality of life is falling rapidly. This is partially due to explosive transport growth with ensuing traffic jams, air pollution and accident risks. Rising vehicle ownership, enhanced urbanisation and poor road infrastructure increase the risk of traffic accidents in many developing countries (Federal Ministry for Economic Development [4] and World Bank [2]). 
Developing countries are facing what we term in this paper "a sustainable transport solutions crossroads" phenomenon. This transport phenomenon is associated with the need to address the following indicated challenges:

1. What is the optimal sustainable transport development pathway or model for developing countries given the realities of dwindling oil supplies, food security and climate?

2. How best can developing countries tackle existing transport gridlock problems and embark on a transport quantum leap that will advance more sustainable transport outcome for such countries?

3. Do developing countries have the critical mass of experts to drive the agenda?

4. Do they know the catalytic transport interventions and investments that will make un-reversible impact in terms of transport solution advancement?

The above questions form part of the jigsaw regarding the sustainable transport solutions crossroads challenge that this paper seeks to unpack.

\subsection{Purpose}

The major aim of this paper is to unravel and identify the sustainable transport solution crossroads matters impacting on developing countries. Once the principal issues of sustainable transport solutions crossroads are identified, strategies and measures to reverse the negative impacts are crafted and discussed. The major research questions that guide the development of this paper include the following objectives:

1. Identify the sustainable transport solutions crossroads headline issues in developing countries;

2. Conduct a rapid appraisal of the sustainable transport solutions crossroads matters;

3. Generate some transport strategies and options that can be employed by developing countries in the march to anchor sustainable transport solutions.

\section{Research methods}

The research methodology is based on an extensive desktop review of literature in the public domain. This literature has been synthesized and analysed to compile this article.

\section{Literature review}

Despite the crucial importance of the transport sector for development, many developing countries have significant deficits in this sector. In particular, financing the entirety of the transport sector often remains an unsolved problem. 


\subsection{Unlocking the sustainable transport solutions crossroad gridlock in developing countries: what has been, what is and what can be?}

Unlocking the sustainable transport solutions crossroad gridlock matters in developing countries requires a multi-pronged analysis. The lack of implementation of a critical mass of sustainable transport solutions that can change the transport landscape significantly can be viewed as a problem. This especially affects the poor in inaccessible rural areas in developing countries, but also the poor living in the suburbs and slums of large and mega cities. The poor often have neither access to transport nor the possibility to escape from its adverse effects. An approach that provides excess transport infrastructure and services to meet transport demand (either present or projected) is criticized as unsustainable. Building and constructing more freeways and highways does not solve transport problems in developing countries (Federal Ministry for Economic Cooperation and Development [4]). The consequences of an exploding increase in transport demand in developing countries is gridlocked traffic conditions, increasing environmental pollution and global warming, which are dialogue areas for policy discussion. The increasing demand for mobility can ultimately thwart sustainable development, especially if motorised and individual means of transport are promoted to the exclusion of other forms (Federal Ministry for Economic Cooperation and Development [4]). Political and institutional transport governance reforms need to be implemented simultaneously with any preferred transport development pathway, for which the majority of countries and transport systems are inadequately, or not at all, prepared to undertake.

Overcoming sustainable transport solutions crossroads gridlock challenges will require interventions that are both technical and non-technical, transport discipline specific and non-transport discipline specific. In addition a sustained investment programme of interventions over the long term will lead to positive results rather than ad-hoc and littered investments.

\section{Discussion of study findings and results}

\subsection{Rapid urbanisation in developing countries and the concomitant challenge of responding to transport demand and services}

The population is forecasted to grow exponentially in the developing world, with the majority of growth concentrating in urban areas (Figure 1). As population grows, travel demands also increase (UITP [11]). Consequently, developing cities will be faced with an increase in urban mobility demands that can be supported neither by existing facilities and infrastructures nor by past and current car-centred policies.

Figure 3 presents investment per capita by different regions of the world. What stands out regarding developing countries is that there is little investment in transport infrastructure and services and the picture is gloomier when one looks at the little investment in public transport. 


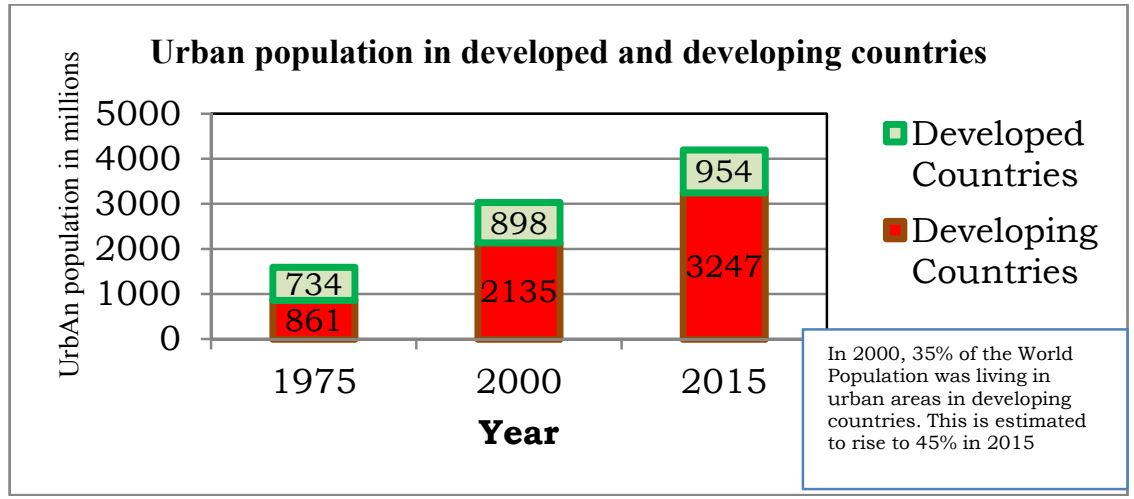

Figure 1: Urban population (source: UITP [11]).

Figure 2 presents the daily trips per capita by different regions of the world. It is clear from the diagram that people in developing countries are making less trips.

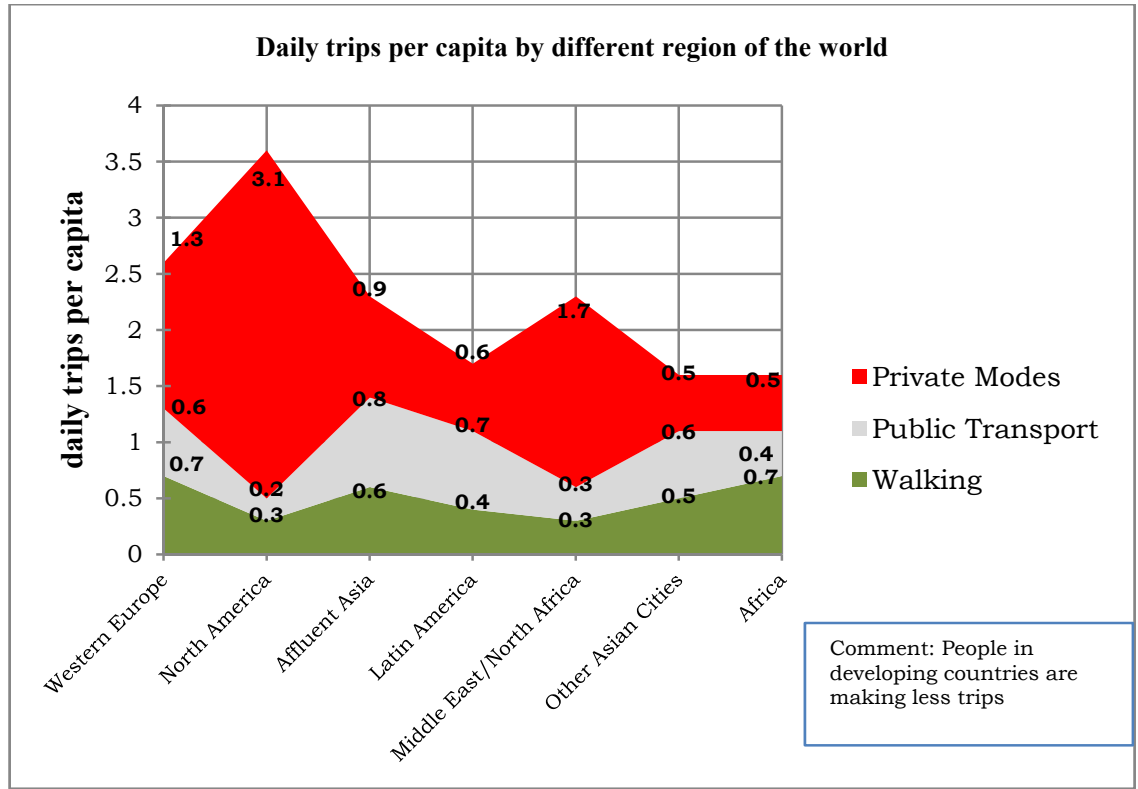

Figure 2: Daily trips per capita by different regions of the world (source: UITP [11]). 


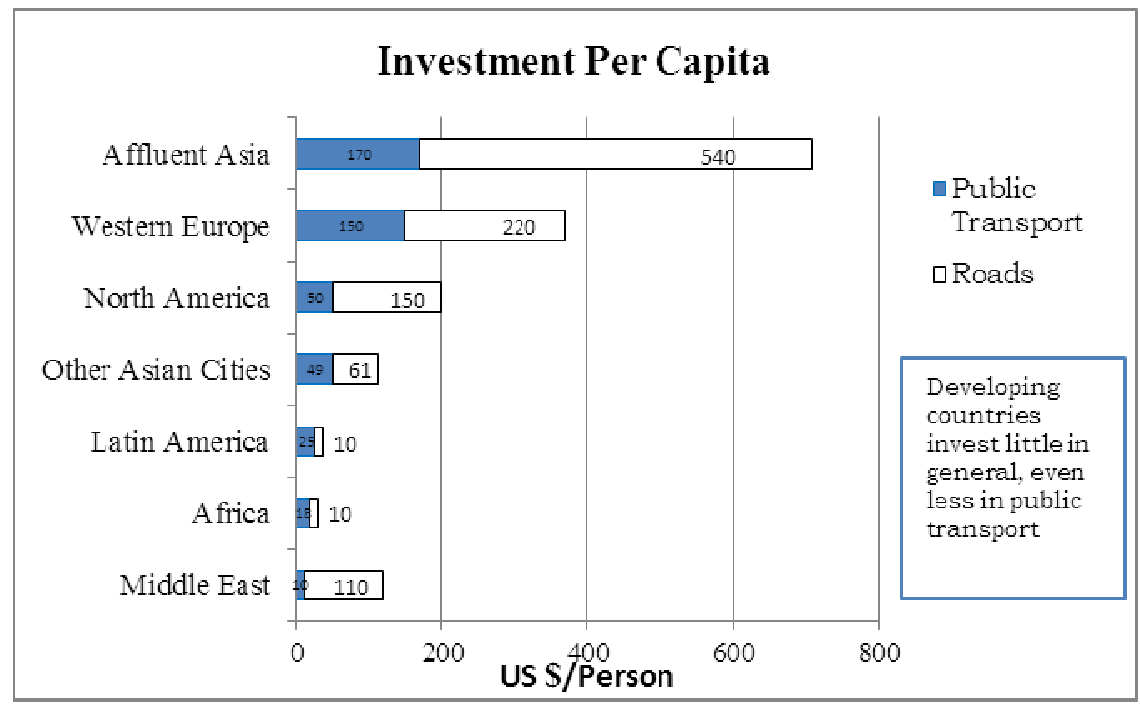

Figure 3: Investment per capita (source: UITP [11]).

The challenges of sustainable mobility in developing countries portrays eight big issues as requiring urgent and continuous monitoring, evaluation and development (Federal Ministry for Economic Cooperation and Development [4]). These main challenges, partly overlapping, partly conflicting, have to be addressed by transportation captains in developing countries in partnership and collaboration with stakeholders in developing and developed countries alike. Figure 4 presents an overview of sustainable transport intervention and options. It also further highlights that implementing sustainable transport solutions should be backed by concomitant improved transport infrastructure and services covering the full transportation mode spectrum. These interventions should make sure that investment, maintenance and the sustainability of infrastructure and services is attained. This is because almost all economic processes are dependent on the transport sector e.g. the supply of raw materials, resources and components, delivery to the retail sector and end-consumers, the organisation of internal corporate communication flows and production activities, to name but a few. Without transport, neither an economic structure based on division of labour, nor integration into the world economy can be achieved. At the same time, economic growth increases the demand for transport.

In addition, as illustrated by Figure 4, the generation of sustainable transport solutions requires that transport sector development must contribute to reducing poverty, climate change and wealth creation. Concerning the transport sector, the poor are disadvantaged since they often have no access to affordable means of transport and thus no access to health care, education, or employment (Chakwizira [5] and World Bank [2]). Non-existent or poor quality road systems, insufficient market access and inadequate and overloaded modes of transport prevent an escape from poverty. In addition, the poor in particular are exposed to 
health risks arising as a result of the negative side effects of transport. Many live and work in areas particularly affected by air pollution, high pollution industrial development corridors and accident-prone risks zones. An escape from this situation of both a lack of mobility and high exposure to the adverse effects of transport is not feasible without substantial support - it requires the implementation of catalytic transport interventions that contribute directly or indirectly to poverty reduction, climate change mitigation and adaptation as well as wealth creation. Overall the rising demand for mobility in developing countries must not thwart the goals of sustainable development.

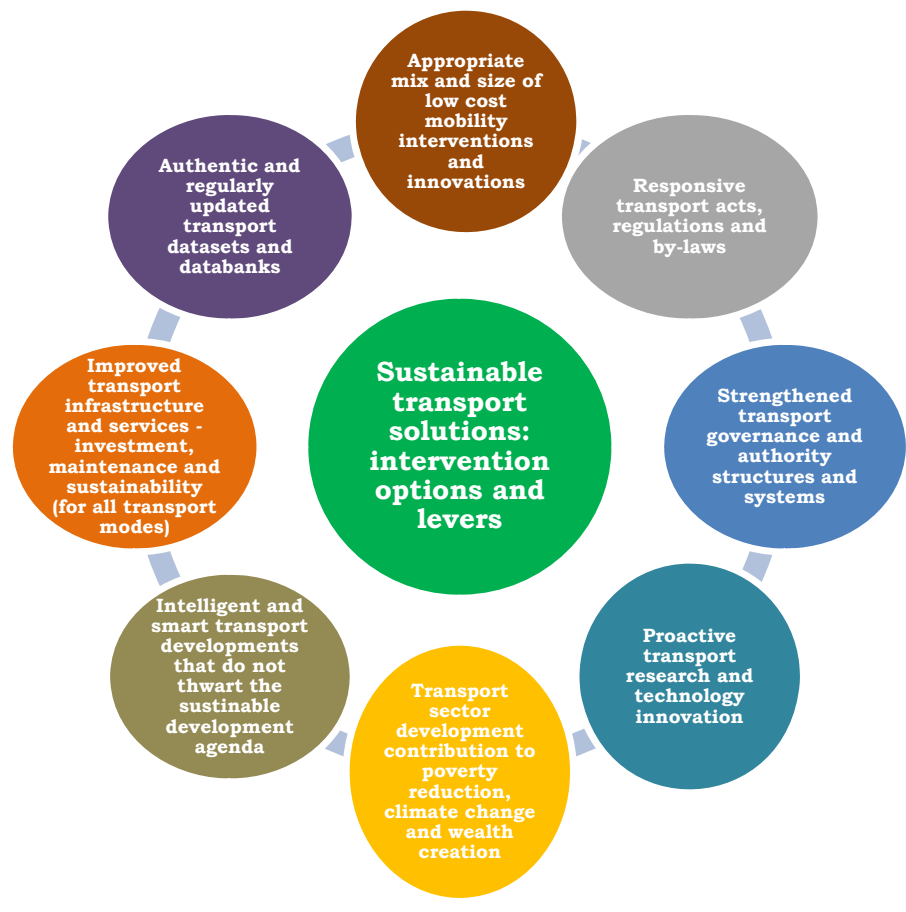

Figure 4: Overview of sustainable transport solutions intervention options and levers continuum.

\subsection{Sustainable transport crossroads: myth or reality?}

A scan of the literature on transport in developing countries may lead one to conclude that we are indeed standing at a crossroads. Developing countries are faced with the 'do nothing' approach (continue with business as usual approach). Following the normal path would be taking the easy way out. It would mean continuing with current transport development policy and trends and hoping for an automatic solution to all social and environmental problems. One can speculate, however, that the results would be fatal - a worldwide increase in poverty, the progressive destruction of our ecosystems and ensuing 
economic, social and political destabilization and crises. The consequences would be borne primarily, but not exclusively, by developing countries. As a consequence of globalisation, all national economies and societies are more intertwined than ever before. Not only economic processes, but also social conflicts, environmental threats and the competition for resources are taking on international dimensions. Industrialized, developing, and newly industrialised countries thus share a common interest in overcoming the "eight challenges" identified in this paper and embarking on sustainable mobility by adopting a different approach.

Developing countries are also faced with the 'do something' approach (embark on a business unusual approach). While it is easy to adopt the traditional approach, it is not so easy to adopt the alternative, which presupposes a fundamental innovative change in the manner of viewing the transport sector. The new paradigm requires that we try to find new solutions to the evolving sustainable transport challenges. Setting a course for sustainable mobility is part of a general reorientation of our production and consumption patterns and way of life. Figure 5 indicates the dual transport solutions crossroads in developing countries.

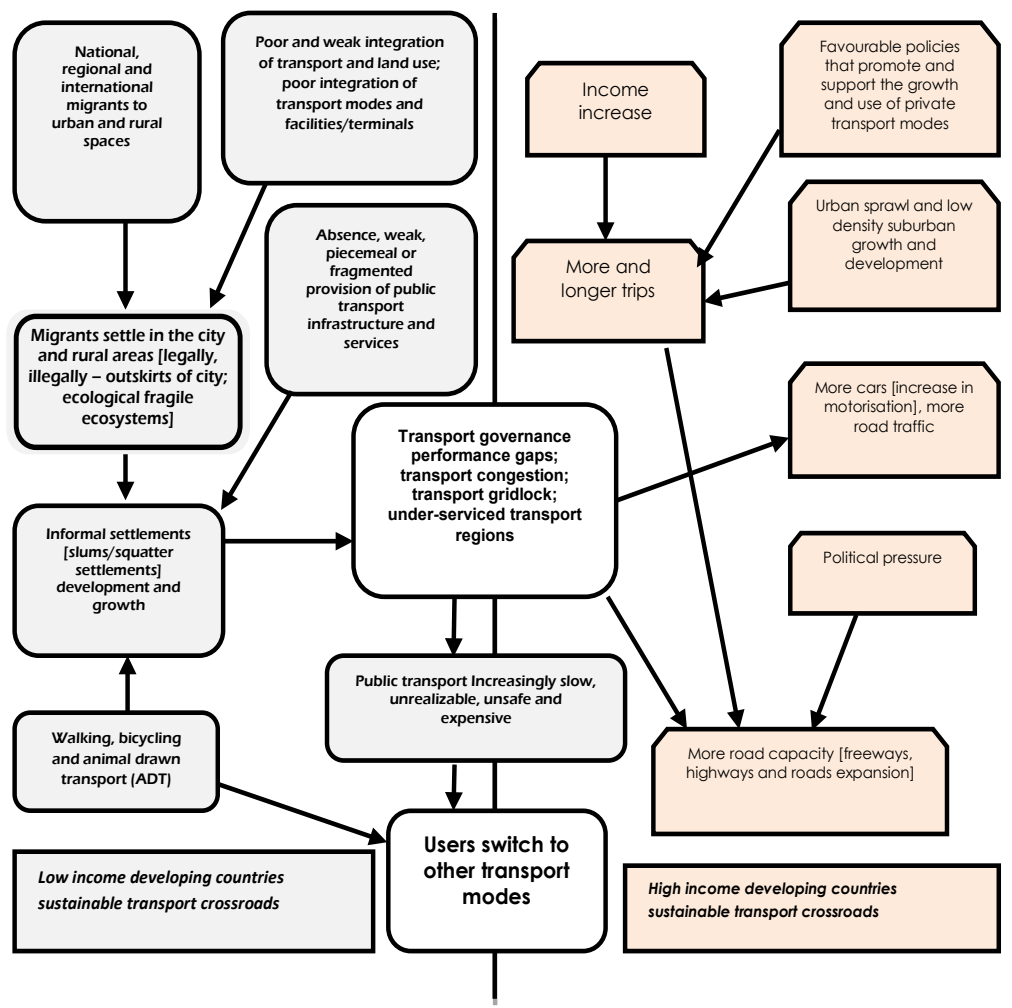

Figure 5: The dual transport solutions crossroads in developing countries hierarchy. 
As indicated in Figure 5, the challenge for developing countries is to grow out of the transport solution crossroads hierarchical loop of problems and start implementing robust, time, scale and dimension changing transport projects and programmes targeted at critical mass level to make meaningful impact and change.

\section{Recommendations}

Sustainable transport systems, made up of a wise mix of different modes of transport, are the basis of stable and sustainable economic development (Table 1). In addition, (cost-) efficient transport infrastructure and services (including innovations) should always be catered for and adapted to the different and diverse needs in urban and rural areas. In light of the sustainable transport solutions crossroads challenge facing developing countries transport planning and policy in conurbations, urban and rural areas must address the following issues:

- Promotion of a healthy balance regarding the construction, provision, delivery and maintenance of non-motorised and public transport infrastructure and services (Kumar and Barrett [1] and Chakwizira et al. [6]);

- Robust and proactive implementation of effective transport demand management through economic incentives, public communications, and education (Chakwizira [5]);

- Increasing and widening the traffic safety dragnet of interventions including incorporating clean air policies for mobile emission sources, and improving technical vehicle inspection;

- Increasing the efficiency of the different transport modes including the road sector, especially by improving rural road construction and maintenance;

- Developing sustainable urban transport systems by improving public transport services and non-motorised transport including the introduction of green public routes, green public transport, green public roads in a phased approach etc.;

- Improving infrastructure management and financing systems through adoption approaches such as Build-Own-Operate (BOO), Build-OwnOperate-Transfer (BOOT) etc.;

- Transport Governance systems such as the advisability of transport authorities to manage large megapolis etc. (Chakwizira and Mashiri [12], World Bank and ADB [9] and Kumar and Barrett [1]).

In making the change and seeking to go over the obstacles relating to sustainable transport solutions, developing countries are encouraged to adopt the A-S-I (Avoid-Shift-Improve) sustainable transport approach. Table 2 summarises the action that different developing countries can adopt based on the context and transport realities. 
Table 1: Recommendations for action in developing countries.

\begin{tabular}{|c|c|c|}
\hline $\begin{array}{c}\text { Catalytic sustainable } \\
\text { transport intervention niche } \\
\text { areas } \\
\end{array}$ & $\begin{array}{l}\text { Policy analysis in the } \\
\text { transport sector }\end{array}$ & $\begin{array}{l}\text { Recommendations for } \\
\text { developing countries }\end{array}$ \\
\hline $\begin{array}{l}\text { Centrality of infrastructure for } \\
\text { growth and job creation in } \\
\text { developing countries }\end{array}$ & $\begin{array}{l}\text { Transport is critical for } \\
\text { low carbon/green growth }\end{array}$ & $\begin{array}{l}\text { Advocate for sustainable } \\
\text { transport as a key part of } \\
\text { sustainable development }\end{array}$ \\
\hline $\begin{array}{l}\text { Focus on } \\
\text { exemplary/transformational } \\
\text { projects }\end{array}$ & $\begin{array}{l}\text { Transformational } \\
\text { opportunities exist in } \\
\text { getting sustainable } \\
\text { transport right, but trade } \\
\text { off exists and careful } \\
\text { cost-benefit analysis is } \\
\text { required }\end{array}$ & $\begin{array}{l}\text { Support the development } \\
\text { of an umbrella toolkit, } \\
\text { based upon existing } \\
\text { sustainable transport } \\
\text { toolkits, to present a menu } \\
\text { of options for critical } \\
\text { planning, design and } \\
\text { policy issues. }\end{array}$ \\
\hline $\begin{array}{l}\text { Enhanced support for capacity } \\
\text { building (local, expertise } \\
\text { development and co-ordination) }\end{array}$ & $\begin{array}{l}\text { Visionary leadership } \\
\text { should be combined with } \\
\text { local capacity building }\end{array}$ & $\begin{array}{l}\text { Create a "glocal" capacity } \\
\text { development facility and } \\
\text { develop new leadership } \\
\text { programme on sustainable } \\
\text { transport solutions in } \\
\text { developing countries } \\
\end{array}$ \\
\hline $\begin{array}{l}\text { Developing countries } \\
\text { infrastructure data } \\
\text { benchmarking }\end{array}$ & $\begin{array}{l}\text { Lack of core transport } \\
\text { data and information } \\
\text { results in poor } \\
\text { investment and decision } \\
\text { making }\end{array}$ & $\begin{array}{l}\text { Create "glocal" including } \\
\text { regional, district and city- } \\
\text { level database to quantify } \\
\text { externality impacts and } \\
\text { assist in better decision } \\
\text { making on sustainable } \\
\text { transport investment }\end{array}$ \\
\hline $\begin{array}{l}\text { Lack of funding for project } \\
\text { preparation, Scope for } \\
\text { assessing/rationalizing existing } \\
\text { project preparation facilities for } \\
\text { enhanced effectiveness, if } \\
\text { necessary }\end{array}$ & $\begin{array}{l}\text { Lack of grant support for } \\
\text { pre-feasibility and } \\
\text { feasibility analysis limits } \\
\text { the market potential for } \\
\text { scaling-up successful } \\
\text { sustainable transport } \\
\text { interventions }\end{array}$ & $\begin{array}{l}\text { Establish a grant based } \\
\text { financing facility to } \\
\text { support preparation of } \\
\text { sustainable transport } \\
\text { solution projects }\end{array}$ \\
\hline $\begin{array}{l}\text { Increased role for private sector } \\
\text { financing }\end{array}$ & $\begin{array}{l}\text { Policies and investments } \\
\text { in sustainable transport } \\
\text { solutions are a public } \\
\text { choice. A public-private } \\
\text { partnership (PPP) is not } \\
\text { always the lowest cost } \\
\text { option: appropriate } \\
\text { allocation of risks is } \\
\text { required }\end{array}$ & $\begin{array}{l}\text { Consider the benefits to } \\
\text { carefully -managed } \\
\text { competition between } \\
\text { public sector (regulator) } \\
\text { and private sector (service } \\
\text { supplier); Adopt PPP } \\
\text { approach under specified } \\
\text { circumstances }\end{array}$ \\
\hline
\end{tabular}

Adopted: World Bank [2], World Bank and ADB [9]. 
Table 2: Possible sustainable transport solutions for developing countries.

\begin{tabular}{|l|l|l|}
\hline \multicolumn{1}{|c|}{ Strategy } & \multicolumn{1}{|c|}{$\begin{array}{c}\text { Rapidly industrializing } \\
\text { developing countries }\end{array}$} & $\begin{array}{c}\text { Low and middle income } \\
\text { developing countries }\end{array}$ \\
\hline Avoid & $\begin{array}{l}\text { Reduce vehicle kilometres through } \\
\text { Transport Demand Management, } \\
\text { land use planning, Information and } \\
\text { Communication Technologies } \\
\text { (ICT), localized production, and } \\
\text { shorter supply chains }\end{array}$ & $\begin{array}{l}\text { Avoid unnecessary } \\
\text { generation of vehicle } \\
\text { kilometres through land use } \\
\text { and transport planning }\end{array}$ \\
\hline Shift & $\begin{array}{l}\text { Shift from private vehicles to non- } \\
\text { motorised transport and public } \\
\text { transport, and from aviation to rail, } \\
\text { transfer freight from road to rail } \\
\text { and water transport }\end{array}$ & $\begin{array}{l}\text { Enable conditions for the } \\
\text { lowest-emitting moves (both } \\
\text { freight and passenger). } \\
\text { Ensure attractive alternatives } \\
\text { to private vehicles exist }\end{array}$ \\
\hline Improve & $\begin{array}{l}\text { Improve existing vehicles. Down- } \\
\text { scale vehicle engine size. Increase } \\
\text { penetration of electric vehicles and }\end{array}$ & $\begin{array}{l}\text { Ensure future vehicles/fuels } \\
\text { are cleaner, encouraging } \\
\text { small, efficient cars. Design } \\
\text { innovations for traditional } \\
\text { non-motorised transport }\end{array}$ \\
& $\begin{array}{l}\text { carbon -neutral liquid fuels. Use } \\
\text { Intelligent Transport Systems } \\
\text { (ITS). Electricity rails (for both } \\
\text { freight and passengers) }\end{array}$ & \\
\hline
\end{tabular}

Source: UNEP [10], World Bank and ADB [9].

\section{Conclusion}

It is vital to draw on international experience, identify country and situationspecific solutions and ensure funding if developing countries are to overcome obstacles towards charting a different transport sustainability path as a reality. Partnership and collaboration between nations, research institutions and industry can potentially contribute towards achieving these goals through important stimuli, advisory services, capacity building, and supportive measures. Close co-operation between transport institutions, planning authorities and development institutions is important in developing a new transport sustainability science intelligence that will allow developing countries to leapfrog from the current crossroads onto a superhighway of sustainable and better transport alternatives and options implementation.

Transport pilot studies, demonstration projects as well as experimenting with different sustainable transport proto-types is one way of attempting to generate appropriate transport solutions for developing countries. Caution needs to be taken to avoid re-inventing the wheel in all these initiatives. Harvesting best transport solutions from developed countries, developing countries including in-country cases should be central to efforts aimed at changing the face of transport problems in developing countries. Crafting sustainable transport solutions will not be easy as the transport crossroads mixed bag is complex and requires sustained transport investment in relevant transport skills, flexible and progressive transport legislation, responsive transport institutions and better transport governance. 


\section{References}

[1] Kumar A \& Barrett F (2008). Stuck in Traffic: Urban Transport in Africa, World Bank, Washington, DC. pp. 1, 3, 8, 12, 15, 18 \& 23.

[2] World Bank (2010). Economic Cities as Ecological Cities, World Bank, Washington D C.

[3] World Bank (2012). The Right Turn - Ensuring Development Through a Low-Carbon Transport Sector, World Bank, Washington DC.

[4] Federal Ministry for Economic Co-operation and Development (2007). Transport and Mobility - Fostering Sustainable and equitable Development, GIZ, Germany. pp. 4, 6, 14, 15 -17, 32 \& 34.

[5] Chakwizira J (2007). The Question of Congestion \& Decongestion in the Greater Johannesburg Area: Some Perspectives, 26th Annual Southern African Transport Conference and Exhibition, Pretoria, South Africa, 9-12 July 2007: ISBN 1-920 - 01702 -X, pages 499, 500, 507, $739 \& 747$.

[6] Chakwizira J, Bikam P \& A.T. Adeboyejo (2011). "Functional and dysfunctional urban mass transportation systems in the greater Gauteng region of South Africa”. Pages 737-748, Sustainable Development and Planning V (2011) Edited by C. A. Brebbia \& E. Beriatos, ISBN 978-184564-544-1; ISSN: 1746-448X (Print); ISSN: 1743-3541 (online) WIT Press, Southampton, Boston.

[7] Chakwizira J, Bikam P, Dayomi M \& Adeboyejo A.T (2011). Some Missing Dimensions of Urban Public Transport in Africa: Insights and Perspectives from South Africa. The Built \& Human Environment Review, Volume 4, Special Issue 2. 2011. p. 57.

[8] Haq G, Schwela D (2012). Transport and Environment in Sub-Saharan Africa, Stockholm Environment Institute, Sweden. pp. 6 \& 12.

[9] World Bank and ADB (2012). Cities at a Crossroads: Unlocking the potential for green urban transport, World Bank, Washington, ISBN: 9780-615-65463-8. pp. 6, 7, 14, 18 \& 22.

[10] UNEP (2011). Cities - Investing in Energy and Resource Efficiency, Green Economy Report, UNEP.

[11] UITP, (2012). Better Urban mobility in Developing Countries - Problems, Solutions and good Practices, UITP, Brussels, Belgium. pp. 3, 6 \& 7.

[12] Chakwizira J, Mashiri M (2009). The contribution of transport governance in socio-economic development in South Africa, Sustainable Transport: 28th Annual Southern African Transport Conference (SATC) 2009, Pretoria, South Africa, 6-9 July 2009, pp. 1-18, ISBN: 9781920017392. 